\title{
CECHY JAPOŃSKIEGO I POLSKIEGO JEZYKA PRAWA
}

\author{
Yuki HORIE, dr \\ Paula TRZASKAWKA, mgr \\ Zakład Legilingwistyki i Języków Specjalistycznych \\ Instytut Językoznawstwa \\ Wydział Neofilologii, Uniwersytet im. Adama Mickiewicza \\ al. Niepodległości 4, 61-874 Poznań, Poland \\ pupu@amu.edu.pl \\ paula.trzaskawka@amu.edu.pl
}

\begin{abstract}
Abstrakt: Temat pracy wybrano, ponieważ cechy języka prawa nie zostały jeszcze opisane we wskazanej parze językowej. Celem pracy jest omówienie tych cech w japońskim i polskim języku prawnym i prawniczym. Autorki przedstawiają cechy języka prawa, posługując się definicjami i przykładami z polskiej i japońskiej ustawy o prawie autorskim i przykładami terminologii narodowej czy sądowej. Owe ustawy, jak i terminologia są zarazem materiałem badawczym. Metoda badawcza, która została obrana, opiera się na obserwacji empirycznej wskazanego materiału badawczego. Autorki skupiają się na omówieniu takich cech, jak: polisemia i homonimia, synonimy, metafory, faux amis czy terminy fachowe/specjalistyczne. Dodatkowo zarysowano różnice pomiędzy językiem potocznym a językiem prawnym i prawniczym. Praca ma charakter poglądowy. Wybrano tylko niektóre cechy języka prawa. W dalszych badaniach należałoby poszerzyć ten opis o większą ilość cech i przykładów.

Słowa kluczowe: cechy języka, język prawny, język prawniczy, wieloznaczność, polisemia, homonimia, homofony, synonimia, metafory, eufemizmy, archaizmy, termin fachowy, zapożyczenia, język ogólny, analiza językowa
\end{abstract}

\section{THE FEATURES OF THE JAPANESE AND POLISH LANGUAGE OF LAW}

\begin{abstract}
The subject of the paper was chosen because the features of language of law have not been described in every language pair yet. The aim of the paper is to discuss the features of the Japanese and Polish language of law. The presented features were taken from Polish and Japanese copyright acts, national terminology and language used in courts. The method focuses on empirical studies. The authors of the paper focus on the following features of language of law: polysemy and homonymy, synonyms, metaphors, false friends (faux amis) or specialized terminology, as well as differences between colloquial language and the varieties of the language of the law. The paper has an outlook nature. Only some features of language of law were chosen. In the nearest future the description of these features should be broadened, as well as the examples.

Key words: features of language, language of law, polysemy and homonymy, homophones, synonyms, metaphors, euphemisms, specialized terminology, borrowings, colloquial language, linguistic analysis
\end{abstract}


日本語とポーランド語の法律用語における特徴

\begin{abstract}
要約 : 日本語とポーランド語の法律用語および法的言語について、両国の法律で定めら れている定義をもとに、その意味や機能、言語的特徵を考察する。研究の結果をもとに、 専門用語の最も興味深い特徵－多義語、同音異義語、同義語、隱喻、専門的使用法などの 特徵をもとに分析し例を提示する。また、法律用語として使用した場合と日常用語として 使用した場合に意味が違う専門用語や、一般の人には使われない法律分野の業界用語など も紹介する。ただし、このような特徵は法律用語の一部に見られ、すべての特徴を兼ねそ ろえているわけではなく、このような特徴はあくまで一例である。 キーワード : 言語の特徵、法律用語、法的言語、あいまいさ、多義語、同音異義語、同 義語、メタファー、隠喻、古語、業界用語
\end{abstract}

\title{
Wprowadzenie
}

Cechy języka prawa nieczęsto ukazywane są jako istotne czynniki wpływające na przekład. W artykule zwrócono uwagę na istotę wybranych cech języka prawa w polskim i japońskim języku prawnym i prawniczym, na terminologię prawną i prawniczą w parze polsko-japońskiej, w której oba wyżej wymienione czynniki mogą mieć wpływ na przekład.

Badania nad polskim językiem prawnym i prawniczym są stosunkowo młode, bo rozróżnienie na te dwa języki zaproponowane przez Wróblewskiego miało miejsce w 1948 roku. Jednakże przed tym rokiem polskie prawo posiadało już wiele archaizmów czy latynizmów, dysponowało swoistymi cechami, które wiązały się z językiem prawnym czy prawniczym, jednak nie było to nazwane specjalistycznie, tak jak to uczynił Wróblewski. Natomiast systematyzacją zainteresowali się badacze późniejsi, nie tylko z polskiego obszaru, którzy powzięli trud skategoryzowania pewnych terminów, podziału ich na różne kategorie czy sklasyfikowania ich według pewnych zasad (por. Alcaraz i Hughes 2002, Zieliński 2004, Mattila 2006, Cao 2007, Galdia 2009).

Mówiąc o terminologii japońskiej, w wyniku błyskawicznego tłumaczenia praw z krajów Zachodu na język japoński w okresie Meiji, prawo to wzbogaciło się o liczne neologizmy oraz słowa nieużywane $\mathrm{w}$ języku potocznym. Jako przyczynę często błędnych tłumaczeń podać można wielką liczbę homofonów i homonimów w języku japońskim. Język japoński zawiera wiele słów powstałych poprzez składanie ideogramów przejętych z Chin, czyli złożeń (jap. 熟語, jukugo). Dopasowywanie znaków o podobnych znaczeniach umożliwia powstawanie wyrazów o znaczeniu różniącym się niewielkimi niuansami, co wzbogaca możliwości wyrażania myśli i sprawia, że japońskie słownictwo jest bardzo bogate. Dlatego w języku japońskim funkcjonuje wiele homofonów, które różnią się niuansami znaczeniowymi. Różnica pomiędzy polskimi homonimami a japońskim homofonami jest taka, że w polskim są one homograficzne, podczas gdy $\mathrm{w}$ japońskim allograficzne, więc trudność może być jedynie natury słuchowej, jeśli chodzi o wartość semantyczną komunikatu. Dla przykładu polskie słowa „wskazywać” i „dźgać”, „pchać” (np. nożem) w japońskim wyrażane są czasownikiem 
sasu. Jednakże w znaczeniu „wskazywać” zapisuje się je ,指す” sasu, a w znaczeniu „dźgać” zaś ,,刺す” sasu. Jeżeli wszakże sędzia zapyta oskarżonego: „Czy pan sashita (forma przeszła od sasu) pana A ołówkiem?”, pytanie to można zrozumieć na dwa sposoby. Jeżeli w tym kontekście wykorzystanym przedmiotem byłby nóż, założyć można, że chodzi tu o „dźganie” - 刺すsasu, jeżeli zaś oskarżony wykonywałby czynność palcem, zapewne chodziłoby o „wskazywanie” - 指す sasu. Jednakże nawet w tym przypadku nie możemy mieć stuprocentowej pewności.

Słowa, które niosą tego rodzaju zagrożenie (wieloznacznością), zazwyczaj zamienia się na inne wyrazy lub też dodaje się do nich wyjaśnienie. Na przykład zamiast czasownika „dźgać” - 刺す(sasu) stosuje się czasownik 突き刺す(tsukisasu) lub zwrot ナイフで危害を与える (naifu de kigai o ataeru; dosł.: „uczynić szkodę nożem”), zaś w przypadku czasownika „wskazywać” - 指す sasu czasownik 指差す(yubisasu; dosł.: „wskazywać palcem”).

Terminologia, określone zwroty czy frazy, podobne do opisanych pokrótce powyżej, zostały zanalizowane i opisane $\mathrm{w}$ dalszej części pracy. Podzielono je na dwanaście kategorii, których opisy wraz z przykładami zostały przedstawione poniżej.

\section{Metoda badawcza}

Obraną metodą badawczą $\mathrm{w}$ niniejszym artykule jest analiza literatury przedmiotu i obserwacja empiryczna oraz porównanie tekstów porównywalnych ${ }^{1}$ (m.in. teksty ustaw polskich i japońskich).

Zakres metody badawczej opiera się na szeroko pojętym prawie cywilnym i karnym, materialnym i procesowym w obu analizowanych językach.

Zasadniczo wybrane przez autorki cechy występują w obu wariantach języka. Jednakże każdy z nich posługuje się innymi definicjami dotyczącymi podziału na język prawa - język prawny i język prawniczy.

Jak już wspominałyśmy, w Polsce język prawny i język prawniczy zostały rozróżnione w 1948 roku przez Wróblewskiego. Uważa się go za twórcę definicji języka prawnego i prawniczego w polskiej literaturze przedmiotu. Ściślej mówiąc, pisze on o języku prawnym jako języku aktów prawnych. Językiem prawniczym nazywa zaś taki język, którym posługują się prawnicy.

W literaturze przedmiotu mówi się o „tekstach paralelnych”, jednakże obecnie mówi się o „tekstach porównywalnych". Teksty paralelne to teksty tego samego gatunku w dwóch różnych językach, bądź jego thumaczenie. Dziś mówimy, że tekstem paralelnym jest oryginał i jego thumaczenie, a teksty porównywalne to teksty tego samego gatunku, o tej samej tematyce w dwóch różnych językach (por. Kubacki 2012, 176-184). 
Natomiast, jeśli chodzi o język używany przez prawników w Japonii, można podzielić go na „terminologię prawną” (jap.法律用語 hōritsu yōgo), stosowaną w przepisach prawa; „terminologię prawniczą” (jap.法曹用語 hōsō yōgo), stosowaną przez sędziów, adwokatów i prokuratorów; oraz „terminologię potoczną” (jap.日常用語 nichijō yōgo), stosowaną w życiu codziennym przez przeciętnego obywatela. Jednakże podział ten jest nieostry i nie jest jasne, do której grupy zaliczyć można niektóre słowa.

Przedmiotem niniejszej analizy uczyniono charakterystykę tzw. „terminologii naukowej” (jap.学術用語 gakujutsu yōgo), związanej z językiem prawa i trudno zrozumiałej w kontekście życia codziennego. Terminologia prawa bazuje w znacznej mierze na słownictwie języka ogólnego, ale podlega różnym uściśleniom. Funkcjonuje ona jako terminologia prawnicza, terminologia tzw. „zastosowania prawniczego" (jap.法的使用法 hōteki shiyōhō), terminologia używana potocznie (w ustawach, kodeksach, sądach etc.). Tę terminologię można również rozróżnić na taką, która jest stosowana przez prawników i laików w różnych kontekstach sytuacyjnych, która nabiera wówczas nieco innego znaczenia lub będzie inaczej odczytywana niż w pierwszym przypadku.

\section{Wyniki badań}

Do cech języka prawnego i prawniczego należeć będą:

1. wyrażenia wieloznaczne (np. polisemia i homonimia),

2. archaizmy,

3. zwroty łacińskie (wciąż są obecne w tekstach prawnych, choć nie we wszystkich krajach; w j. japońskim zwrotów łacińskich nie ma),

4. zapożyczenia (głównie $\mathrm{w}$ tej pracy pojawiać się będą $\mathrm{w}$ języku japońskim - wiele z języka chińskiego czy angielskiego),

5. metafory,

6. eufemizmy,

7. wulgaryzmy (podczas przekładu prawniczego tłumacze muszą się także borykać z przekładem wulgaryzmów, których co prawda brak w tekście pisanym, ale są one obecne $w$ tekstach tłumaczonych ustnie, np. na komisariacie policji czy sali rozpraw, gdzie Kodeks ttumacza przysięgłego wymaga od thumacza, by przekładał całość wypowiedzi świadków bez wprowadzania zmian),

8. fałszywi przyjaciele (faux amis),

9. neologizmy,

10. synonimy,

11. terminy o nieostrym znaczeniu,

12. terminy fachowe,

13. terminologia języka prawa a słownictwo języka ogólnego.

14.

Wspomniane cechy języka prawa można odnaleźć w artykule Aleksandry Matulewskiej pt. „Jakość przekładu prawniczego a cechy języka prawa” oraz monografiach tej samej autorki $(2007,2013)$. 
Natomiast David Mellinkoff (1963) wyróżnia cechy języka prawa, skupiając się na jego archaiczności i na terminach wieloznacznych (mających inne znaczenie w języku potocznym i języku prawa), które zostały $\mathrm{w}$ polskim przekładzie prawnym zaklasyfikowane pod kategorią polisemii i homonimii.

Oprócz powyższych właściwości Mellinkoff wyróżnia dziewięć cech języka prawa:

1. „frequent use of common words with uncommon meanings,

2. frequent use of Old English and Middle English words once on common use, but now rare,

3. frequent use of Latin words and phrases,

4. use of Old French and Anglo-Norman words which have not been taken into the general vocabulary,

5. use of terms of art,

6. use of argot,

7. frequent use of formal words,

8. deliberate use of words and expressions with flexible meanings,

9. attempts at extreme precision of expression" (Mellinkoff 1963,11).

Dodatkowo poza wypunktowanymi powyżej cechami języka prawa, Mellinkoff do osobnej kategorii wlicza swego rodzaju manieryzmy, których używają prawnicy w profesjonalnych rozmowach (por. Mellinkoff 1963, 24-29).

\section{Terminy o nieostrym znaczeniu}

Terminy o nieostrym znaczeniu mogą powodować najwięcej niejasności w przekładzie. Idąc za Malinowskim, terminy o nieostrym znaczeniu to takie terminy, które należą do „nazw intuicyjnych” (2006, 145). „Nazwą intuicyjną jest nazwa generalna, której treść nie jest wyraźna, tzn. zespół cech konstytutywnych nie pozwala na jednoznaczne wytypowanie każdego z jej desygnatów. Nazwę taką określa się także jako nazwę o znaczeniu intuicyjnym, ponieważ zaklasyfikowanie obiektu do zakresu nazwy jest czynnością w jakimś stopniu intuicyjną, zawierającą ocenę/oceny” $(2006,145)$.

\section{Wieloznaczność}

W ramach wieloznaczności wyróżnia się polisemię i homonimię (por. Sourioux i Lerat 1975). Jednakże coraz trudniej jest określić, czy dany termin jest polisemem czy homonimem w języku prawnym i prawniczym. W przypadku polisemii mówimy o takich terminach, których wspólne znaczenie można odnaleźć za pomocą badań diachronicznych, natomiast $\mathrm{w}$ przypadku homonimii pochodzenie wyrazów jest zatarte i trudne do ustalenia.

\section{Polisemia}

Sourioux i Lerat $(1975,94)$ wyróżniają polisemię prawniczą i polisemię językową. Polisemia prawnicza polega na tym, iż jeden termin posiada różne znaczenia w języku prawa i języku innej dziedziny, np. budownictwa, bądź posiada kilka różnych znaczeń w różnych gałęziach prawa. W przypadku polisemii językowej mamy do czynienia 
z terminami posiadającymi różne znaczenia w języku ogólnym i specjalistycznym, np. w języku prawa.

Wiadomym jest, że język prawa czerpie z języka ogólnego, a w języku ogólnym mamy do czynienia $\mathrm{z}$ wyrazami o wielu znaczeniach. W kontekście prawnym można nadać wyrazowi precyzyjne i nowe znaczenie, jednakże nigdy nie będzie tak, że wszystkie terminy w języku prawa będą „ściśle prawne”. W języku prawa wieloznaczność może mieć różną postać. Czasami będzie ona polegać na tym, że pozostawia się szerszy zakres do interpretacji tekstu, bądź specjalnie poddaje się wieloznaczności, by powstały „luki w prawie” tak, by można było je „ominąć” czy uzyskać dodatkowe korzyści. Zieliński $(2006,146)$ o polisemii mówi tak:

Polisemia polega na tym, że jeden termin ma kilka znaczeń $i$ to znaczeń, które w jakiś sposób - nawet daleki - wiąza się ze sobą. Na przyktad (...) wyraz «dom» ma siedem znaczeń. W pierwszym znaczy tyle, co «budynek przeznaczony na mieszkanie, pomieszczenie instytucji itp.», $w$ drugim znaczy tyle co «mieszkanie, pomieszczenie mieszkalne, miejsce stałego zamieszkania, własny kąt». Znaczenia te mają ze soba jakiś określony związek.

Kolejnym przykładem wyrazu polisemicznego jest przytoczona przez Malinowskiego „głowa” $(2006,144)$. Nazwa ta jest, po pierwsze, używana w sensie anatomicznym, po drugie, oznacza rodzaj działalności opodatkowanej (tzw. „głowa medium”), po trzecie, może oznaczać jednostkę statystyczną (tzw. „głowa mieszkańca”) bądź po czwarte, odnosi się do najważniejszej osoby w państwie, tj. ,głowy państwa”.

Poniżej zaprezentowano terminy japońskie cechujące się polisemicznością:

i)

\section{善意 $z e n^{\prime} i$, 悪意 $a k u^{\prime} i$}

W języku japońskim 善意 zen'i to często używane słowo, które oznacza „[działać] w dobrej wierze wobec czegoś lub kogoś”. Jednakże jako termin prawny oznacza on „dobrą wiarę”, wolę osoby wykonującej czynność prawną, niezdającej sobie sprawy z istnienia przeszkód i zmiany faktów. Tak samo jak 善意 zen' $i$, 悪意 $a k u$ 'i jako termin potoczny oznacza „złą wolę, pragnienie skrzywdzenia lub unieszczęśliwienia drugiej osoby”, jednak jako termin prawny, 悪意 $a k u$ 'i oznacza wolę osoby wykonującej czynność prawną, zdającej sobie sprawę z istnienia problematycznych faktów, która działa świadomie. Jeżeli chcemy oddać potoczne znaczenia tych wyrazów terminami prawnymi, musimy powiedzieć odpowiednio kōiteki na ishi, 好意的な意思, „dobra wola”, dosł. „życzliwa wola”, i kashi aru ishi hyōji 瑕疵ある意志表示”, dosł.: „wady oświadczenia woli/wadliwe oświadczenie woli” lub itoteki na kōi 意図的な行為 „,celowe działanie".

ii)

果実 kajitsu

果実 kajitsu jako termin pospolity oznacza „owoc”. Wyraz ten jest często używany: rzuca się w oczy na niemal każdym opakowaniu soku owocowego. Jako termin prawny oznacza jednak ogólnie „korzyść” lub „pożytek”, jaki ludzie czerpią z różnego 
rodzaju działań. Rozróżnia się np. hōtei kajitsu 法定果実, czyli dosłownie „pożytki prawne” - czynsz, odsetki, itp.; oraz tennen kajitsu 天然果実, dosłownie „pożytki naturalne" - plony, rodzące się zwierzęta hodowlane, kopaliny itp.

\section{Homonimia}

Słownik języka polskiego opisuje homonimię jako „identyczność brzmienia i pisowni wyrazów mających różne znaczenia i zwykle też różne pochodzenie". Dodatkowo Polański $(1999,136)$ mówi o homonimii jako „wyrażaniu różnych znaczeń za pomocą identycznej formy językowej”, a homonimami są „te zwroty wieloznaczne, w przypadku których różne znaczenia przypisywane temu samemu terminowi nie mają ze sobą nawet dalekiego związku." Sugeruje się, aby w języku prawa nie tworzyć i nie używać homonimów, gdyż niektóre ze znaczeń terminów mogą być bliskoznaczne, dlatego też wciąż kłopotliwym terminem jest termin „rodzina” i jego znaczenie (czy tworzy ją mąż i żona, czy o rodzinie można powiedzieć dopiero w momencie, gdy jest dwoje rodziców i dziecko?) (Zieliński 1999, 59).

Język prawny jest językiem pisanym, w którym homonimami są wyłącznie słowa o jednakowej pisowni. Homonimy te są nazwami wieloznacznymi, jednakże w konkretnych użyciach danego homonimu wyraz ten jest ujednoznaczniony kontekstowo pomimo swojej wieloznaczności. Kontekst budowany jest poprzez wyrażenia, które składają się na wyraz homonimiczny i w pewien sposób „okalają” homonim. Dzięki takiemu zabiegowi z kontekstu można wywnioskować odpowiednie znaczenie terminu. Według przykładu podanego przez Malinowskiego (2006, 143-144), termin „powód” ,jest przykładem nazwy jednoznacznej w języku polszczyzny współczesnej, która stała się $\mathrm{w}$ języku prawnym homonimem w wyniku nadania jej dodatkowego znaczenia przez legislatora. Nazwa „powód” występuje w języku prawnym w nowym znaczeniu strony procesowej (kodeks postępowania cywilnego), a także w zwykłym znaczeniu przyczyny „powód niesprawności systemu pomiarowego" (rozporządzenie Ministra Środowiska z 4 sierpnia 2003 r. w sprawie standardów emisyjnych z instalacji, Dz. U. Nr 163, poz. 1594).

Kolejnym przykładem omawianym przez Malinowskiego jest termin „wina”, który występuje w ponad 300 aktach normatywnych. W różny sposób rozumiana jest ona w 29 artykułach kodeksu cywilnego, regulacjach karnych i kodeksie pracy, a nawet stosuje ją do określenia napoju alkoholowego (liczba mnoga od „wino”).

Przykład podany przez Zedlera (2003, 94), który posiada wiele znaczeń i jest kłopotliwy dla thumaczy, to termin „kurator”. W polskim prawie termin ten występuje w ponad dwudziestu znaczeniach. Instytucja kuratora pojawia się w kodeksie cywilnym, kodeksie postępowania cywilnego, kodeksie rodzinnym i opiekuńczym, prawie upadłościowym i naprawczym oraz w kodeksie karnym.

\section{Homofony}

Słownik języka polskiego opisuje homofon jako „wyraz w warstwie dźwiękowej identyczny $\mathrm{z}$ innym wyrazem, odmienny jednak od niego w warstwie znaczeniowej, a także graficznej, np. morze i może, buk i Bóg.” W języku japońskim ze względu na pisownię (ideogramy) wieloznaczność występuje przede wszystkim w języku mówionym. 
Dwa różne znaki czytane w ten sam sposób mogą powodować nieporozumienie i błąd w odbiorze słowa wypowiadanego, jeżeli kontekst sytuacyjny nie jest wystarczający. Poniżej zaprezentowano przykłady homofonów w języku japońskim wraz z objaśnieniem.

\section{i) Kyōhaku, 強迫 / 脅迫}

Oba słowa znaczą ,grozić”, jednak 脅迫 kyōhaku stosowane jest w prawie karnym, 強迫 kyōhaku zaś w cywilnym. 強迫kyōhaku to „grozić”, „straszyć”. Ponieważ stosuje się ten termin w kontekście prawa cywilnego, używa się go na przykład dla określenia groźby w sytuacji, gdy brak realizacji zobowiązania doprowadzi do zajęcia własności. 脅迫 kyōhaku stosowane w prawie karnym jest silniejszą groźbą, ,informacją, że zostanie wyrządzona szkoda dotycząca życia, zdrowia, dobrego imienia lub wolności osoby”. „Zabiję cię!” lub „spalę ci dom” to przykłady 脅迫 kyōhaku.

ii)

Sekō, 施工 / 施行

施行 sekō oznacza zastosowanie przepisu prawnego. 施工 sekō z kolei to również realizacja, ale prac budowlanych. Ponieważ jednak realizacja prac budowlanych również oparta jest na przepisach prawa, czasami w odniesieniu do niej także stosuje się 施行sekō.

Mono, 者/物

物 mono to przedmiot, rzecz zajmująca przestrzeń. 者mono to osoba fizyczna, osoba prawna lub instytucja. Ponadto jeżeli zapisuje się mono sylabariuszem hiragana もの mono, wskazuje się wówczas na grupy lub instytucje nieobdarzone osobowością prawną lub na abstrakcyjne zbiory łączące takie grupy lub instytucje $\mathrm{z}$ osobami fizycznymi lub prawnymi.

$$
\text { Tokoro, ところ / 所 }
$$

所 tokoro oznacza określone miejsce, ところ tokoro stosowane jest w znaczeniu treści zdania poprzedzającego. 所 tokoro stosuje się w zdaniach, np. ie o tateru tokoro o sagasu 家を建てる所をさがす „szukam miejsca na budowę domu”. Jako termin prawny jednak chętniej stosowane jest słowo basho 場所 „miejsce”. ところ tokoro stosuje się w takich zdaniach jak na przykład: iken ga itchi shinai baai wa, kaichō no kessuru tokoro ni yoru 意見が一致しない場合は、会長の決するところによる, ,jeżeli opinie nie będą zgodne, zrobimy jak zadecyduje prezes”.

W języku japońskim istnieje bardzo wiele homofonów o różnym znaczeniu, nie jest to więc zjawisko specyficzne dla języka prawnego. W przypadkach, gdy język prawniczy używany jest $\mathrm{w}$ formie ustnej, powoduje on liczne problemy (np. w sądzie, podczas przesłuchiwania stron, thumaczenia środowiskowego etc.). W takich przypadkach występuje potrzeba pokazania zapisanego słowa lub zastąpienia go słowem rdzennie japońskim. 


\section{Synonimia}

Synonimia „polega na wyrażaniu tej samej treści za pomocą dwu (kilku) różnych form językowych" (Polański 1999, 385). Synonimia może być używana w dwóch znaczeniach: semantycznym i stylistycznym, jako wyrazy jednoznaczne i bliskoznaczne (Jadacka 2006, 102). Należy tutaj zaznaczyć, że w świetle badań językoznawczych nie istnieje całkowita synonimia i właściwie należy mówić o terminach bliskoznacznych. Jest to związane z faktem, że terminy takie nie są w $100 \%$ wymienne we wszystkich kontekstach, w jakich występują. Do terminów bliskoznacznych w języku polskim należy zaliczyć np. terminy kontrakt i umowa. Pierwszy $\mathrm{z}$ nich jest stosowany w języku ekonomii, a drugi w języku prawa.

W języku polskim występuje dość niewiele synonimów, natomiast w języku japońskim odnajdziemy wiele terminów prawnych, których znaczenie jest bardzo podobne bądź bliskoznaczne. Poniżej zaprezentowano przykłady użycia synonimii $\mathrm{z}$ wyjaśnieniem.

i)

価額kagaku, 価格kakaku

kagaku (,cena”) to konkretna cena danego przedmiotu, kakaku wartość pieniężna abstrakcyjnego przedmiotu. 価額kagaku to słowo niemal niestosowane na co dzień. Wartość pieniężną danej rzeczy i jej cenę oddaje się zazwyczaj słowem kakaku, jednakże jako termin prawny pierwsze znaczenie niesie kagaku, drugie zaś kakaku. Czasami kagaku zastępuje się terminem 額 gaku.

ii）＼cjkstart直ちに tadachi ni, 速やかに sumiyaka ni

Tadachi ni (,natychmiast”) wskazuje na konieczność natychmiastowego wykonania danej czynności, bez jakiegokolwiek opóźnienia. Sumiyaka ni jest raczej stosowane jako sugestia, nie ma owego czynnika ponaglenia. Istnieje również przysłówek 遅延なく chien naku „bez nadmiernej zwłoki/bez nieuzasadnionej zwłoki”. Obejmuje on niuans znaczeniowy: „nie wolno się spóźnić, ale uzasadnione opóźnienie zostanie usprawiedliwione".

Można zaryzykować stwierdzenie, że im dłużej przeciętni użytkownicy stosują niejednoznacznie i omyłkowo powyższe, niewiele różniące się między sobą terminy i zwroty, tym większy powstaje zamęt. Ich znaczenie jest mniej lub bardziej zrozumiałe, jednakże poprawne zastosowanie już nie. Język prawny wymaga jednak ścisłego wyrażania się, dokładnie zdefiniowanych znaczeń. Dlatego przy posługiwaniu się powyższymi terminami wymagane jest zwrócenie szczególnej uwagi na wybór odpowiedniego słowa, które może mieć odmienne znaczenie w języku potocznym i specjalistycznym. Ponieważ jednak pokrótce opisane różnice w użyciu nie są znane przeciętnym Japończykom, o sporządzenie dokumentów prawnych prosi się zazwyczaj w Japonii specjalistów, głównie prawników. 


\section{Metafory}

Metafora wg Delisle'a opiera się na „figurze stylistycznej w tradycji retorycznej interpretowanej jako porównanie eliptyczne, oparte na analogii istniejącej między jakimiś dwoma konceptami, dwoma przedmiotami, dwoma sytuacjami. Często metafora polega na zastąpieniu pojęcia abstrakcyjnego konkretnym" (Tomaszkiewicz 2004, 59). We współczesnym języku prawa niewiele jest metafor, jest on bardziej neutralny (Mattila 2006, 75). Mimo to pozostało kilka zwrotów posiadających charakter metafory. Według Oksaara metafora cechuje się: „highly useful linguistic means in cases involving something brand new that has to be named. It brings out features analogical to the new and the old. Thanks to a metaphor, it is possible to describe the functions and structure of a phenomenon, without defining it in detail" (Oksaar w Mattila 1989, 221). Przykładowymi metaforami mogą być w polskim języku prawa m.in. ciężar dowodu, źródła prawa czy lwia czesść.

Osoby związane z prawem, np. sędziowie czy adwokaci, często tworzą skróty, które są łatwiejsze dla nich w użyciu, jednak niezrozumiałe dla laika. Na przykład sędziowie, rozmawiając $\mathrm{w}$ restauracji, mówią o sądzie, w którym pracują wagasha わが社 „nasza firma”, aby otaczające ich osoby postronne nie wiedziały, czym się zajmują.

Do szczególnego rodzaju metafor można zaliczyć eufemizmy.

\section{Eufemizmy}

Eufemizmy określa się jako „zastępcze środki językowe (wyraz, wyrażenie lub zwrot) używane w celu uniknięcia wyrazu, wyrażenia lub zwrotu zakazanego przez tabu językowe albo niewskazanego ze względów perswazyjnych. W pierwszym wypadku chodzi o eufemizmy przyzwoitościowo-magiczne (np. ustronne miejsce ustęp; zasnąć na wieki umrzeć), w drugim - najczęściej o eufemizmy propagandowe (np. zająć upatrzone z góry pozycje wycofać się)" (Polański 1999, 90).

Eufemizmy i swego rodzaju kolokwializmy powodują zmianę rejestru, a używa się ich przede wszystkim wtedy, kiedy w żaden inny sposób nie da się określić popełnionego czynu bądź zaistniałej sytuacji (np. przestępstwo, zbrodnia, katastrofa naturalna). Bardzo obrazowym przykładem może być angielska fraza acts of God, która ma szerokie zastosowanie w umowach ubezpieczeniowych i służy wskazaniu „boskiego działania” (w języku polskim siła wyższa), czyli zdarzenia losowego, takiego jak np. powódź czy pożar.

Poniżej przedstawiono japońskie eufemizmy:

i)

婦女暴行 fujo bōkō

W japońskim języku prawnym 婦女暴行 fujo bōkō oznacza dosłownie ,atak (napaść) na kobietę". Eufemizm ten często używany jest przez media masowe, a oznacza on 強姦 gōkan, czyli „gwałt”. Ponieważ znaczenia 暴行 $b \bar{o} k \bar{o}$, ,atak, napaść” i 強茹gōkan „gwałt” znacznie różnią się, są opinie, zgodnie z którymi powinno używać się terminu 
強姦 gōkan, występującego w Kodeksie karnym. Jednak ideogram 姦 kan/midara (nieprzywoitość), który składa się z trzech znaków 女 onna (kobieta), został wskazany przez feministki jako znak dyskryminujący kobietę, więc nadal powszechnie jest używany termin 婦女暴行 fujo bōkō.

\section{Archaizmy}

Za archaizm uznaje się wyrażenie, które wyszło z użycia. Wiele takich wyrażeń wciąż jest obecnych w polskim języku prawa. Wg Zielińskiego $(2006,184)$ archaizm jest wyrazem, ,który nie należy aktualnie do słownictwa czynnego danego języka”, natomiast mówiąc o wyrazie (zwrocie) przestarzałym odnosi się do wypowiedzi u osób starszych (np. kajet - zeszyt, kawaler - młody chłopak).

Mówiąc o polskim języku prawa, wciąż w pismach prawnych czy umowach często używa się archaicznego zwrotu jest obowiazany zamiast jest zobowiazany. Świadczyć to może o dużym przywiązaniu prawników do tradycji językowej, którą przekazują sobie we własnym wąskim gronie.

Zwrotem uważanym za archaiczny w języku japońskim jest にわかには措信しがたい niwaka niwa soshin shigatai (dosł.: „trudno natychmiast położyć zaufanie"). Jest to zwrot często stosowany w sentencji wyroku o znaczeniu: „,niewiarygodny”, „mało wiarygodny” „,niegodny zaufania”, ,trudno w to uwierzyć”.

\section{Termin fachowy}

Każda domena czy dziedzina posiada swój zbiór wyrazów, określeń, które są używane przez specjalistów danej dziedziny. W tym wypadku chodzi o jeszcze bardziej szczegółowy podział, np. zbiór oznaczeń muzycznych (artykulacyjnych czy dynamicznych) ma określone słownictwo. Wspomniany wcześniej Mellinkoff (1963) przytacza przykłady dotyczące burleski, np. wyrażenie „bump and grind” określa specjalny taniec o określonych ruchach wykonywanych przez tancerkę. Z kolei specjaliści od jeździectwa używają takich słów jak „kiełzno” czy „wędzidło”.

W japońskim języku prawa, poza terminologią, jaką można odnaleźć w specjalistycznych słownikach i w przepisach prawa, występuje ponadto język prawniczy, którym posługują się prawnicy, adwokaci i sędziowie. Jest to rodzaj zawodowego żargonu prawniczego. Osoby związane z prawem poprzez tworzenie skrótów i restrukturyzację złożeń, tworzą łatwiejsze w użyciu terminy, które mogą być jednak niezrozumiałe dla osoby niemającej z prawem zbyt wiele wspólnego. Na przykład zbyt długi termin keisatsukan chōsho 警察官調書 „protokół policyjny” skracany jest do piesu (PS, Police statement). Niektóre z tych przykładów obrazują pewne zjawiska, jakie możemy obserwować w japońskim języku prawa. Oto kilka przykładów takich słów i zwrotów:

事件受付 Jiken uketsuke (dosł.: ,przyjęcie sprawy”)

Biuro w sądzie przyjmujące pozwy i wnioski. Pracuje w nim sekretarz sądu, sprawdzający formalną poprawność dokumentów. Uketsuke jest w języku japońskim słowem oznaczającym recepcję w hotelu lub w firmie. 
ii)

弁論権和解 Benronken wakai

Jest to termin, który występował w starym Kodeksie postępowania cywilnego (jap. Mimpō soshōhō, 民法訴訟法). Obecnie nie jest formalnym terminem prawnym; odpowiada mu benron jumbi tetsuzuki (弁論準備手続き, dosł.: „procedura przygotowawcza obrony"). Oznacza on uporządkowanie stanowisk obu stron i próbę zawarcia ugody przeprowadzoną nie na sali sądowej, ale w osobnym pomieszczeniu przeznaczonym do mediacji.

iii)

クレサラ Kuresara

Jest to słowo określające sprawę, która dotyczy osoby niemogącej zwrócić pieniędzy pożyczonych od osób pożyczających na procent wyższy niż przewidziany odpowiednimi przepisami (tzw. sarakin, サラ金). Jest to skrót od: kurejitto sarakin saimu seiri jiken (クレジット・サラ金＼cjkstart債務整理事件, dosł.: „sprawa uporządkowania zobowiązania wobec firm kredytowych i sarakin").

Powyższe słowa $\mathrm{i}$ zwroty są zazwyczaj stosowane w rozmowach między prawnikami, zaś w obecności tłumaczy i innych osób zastępowane są innymi wyrazami.

\section{Terminologia języka prawa a słownictwo języka ogólnego}

Język prawa cechuje specyficzne słownictwo, które dla przeciętnego odbiorcy może być niezrozumiałe. Należy jednak pamiętać, że obok specjalistycznych terminów prawnych można odnaleźć pewien zasób słownictwa zaczerpnięty z języka ogólnego. Wg JopekBosiackiej $(2006,46)$,język prawa jako język specjalistyczny składa się z terminów prawnych/fachowych, jak i wyrażeń języka ogólnego". Według Pieńkosa $(1999,98)$ wyróżnia się trzy grupy terminów w kręgu terminologii języka prawa:

1. terminy języka ogólnego użyte w znaczeniu ogólnym,

2. słownictwo języka ogólnego użyte w znaczeniu specjalistycznym (technicznym),

3. słownictwo wyraźnie specjalistyczne (techniczne).

Bardzo podobnie opisują to Alcaraz i Hughes (2002, 16-18), wyróżniając:

1. technical terms,

2. semi-technical terms,

3. everyday vocabulary.

Należy zauważyć, że terminologia prawna jest na tyle zróżnicowana, że posiada odrębne znaczenia w języku prawa i języku ogólnym bądź może mieć te same znaczenia co w języku ogólnym. Wiele terminów z języka ogólnego może przyjmować nowe znaczenie w kontekście prawa. Dodatkowo język prawa może zawierać języki specjalistyczne z innych dziedzin, takich jak np. budownictwa, rolnictwa, ogrodnictwa czy nawet muzyki.

W języku japońskim przykładowym zwrotem, którego znaczenie różni się w kontekście prawnym i ogólnym może być 並びに narabi $n i$ i 及びに oyobi ni, oba 
wyrazy to spójniki. Prawnie rzecz biorąc 並びに narabi ni ma bardziej ogólne znaczenie. Jeżeli łączy się dwa wyrazy, stosuje się oyobi ni, jeżeli trzy i więcej, oddziela się je przecinkami, a przed ostatnim wstawia oyobi ni. Jeżeli wymieniony na skali ważności przedmiot zajmuje wysokie miejsce używa się narabi ni, oyobi ni zaś używa się, gdy coś jest mniej ważne lub należy do innej kategorii (np. ミカン、バナナ、並びにリンゴ及びにキャベッ mikan, banana, narabi ni ringo oyobi ni kyabetsu (pomarańcza, banan i jabłko oraz kapusta). Jeżeli słowa te występują po czasowniku, przed nim należy wstawić przecinek. Jeżeli w zestawianych słowach istnieje stopniowanie znaczeń, obiekty wyższego rzędu łączy się za pomocą 並びに narabi ni, niższego rzędu zaś 及びに oyobi ni. Na przykład, 新郎並びに新婦 shinrō narabini shinpu ,panna młoda i pan młody” to często używany wyraz, jednak jako termin prawniczy używa się terminu 新郎及びに新婦 shinrō oyobi shinpu. 並びにnarabi ni można stosować, dodając „wszyscy zaproszone goście” ご出席の皆様 goshusseki no mina sama, na przykład: 新郎及び新婦並びにご出席の皆様 shinrō oyobi shinpu narabini goshusseki no mina sama.

\section{Zapożyczenia}

W związku z przystąpieniem Polski do Unii Europejskiej w 2004 roku, wiele unijnych aktów normatywnych zastało przetłumaczonych na język polski. Spowodowało to pojawienie się licznych zapożyczeń m.in. z języka angielskiego. Jak stwierdza Matulewska (2008, 157), zapożyczenia mogą być bezpośrednie, np. egzotyki, czyli zapożyczenia zachowujące pisownię terminu źródłowego (np. copyright, know-how), oraz zapożyczenia, które dostosowują się do pisowni języka docelowego np. umowa leasingowa, leasing, deweloper. Ponadto w polskim języku prawnym i prawniczym pojawiły się hybrydy, kalki (np. kopia od copy, zamiast egzemplarz), neologizmy, latynizmy i różnego rodzaju ekwiwalenty (funkcjonalne, opisowe, zorientowane na język źródłowy, hiponimy).

Przykładem zapożyczenia z języka angielskiego może być termin monitoring. Słownik języka polskiego PWN podaje dwie definicje słowa monitoring: 1.«stała obserwacja i kontrola jakichś procesów lub zjawisk» bądź 2.«stały nadzór nad jakimś obiektem chronionym». Najistotniejszym faktem w tym przypadku jest „stałość" w obserwacji bądź nadzorze. Nie mając odpowiednika w języku polskim, który składałby oba elementy $\mathrm{w}$ jeden wyraz, zostało stwierdzone, że lepszym rozwiązaniem będzie w tym wypadku zapożyczenie.

Harmonizację (za Słownikiem języka polskiego PWN) definiuje się jako: „zestrojenie poszczególnych elementów w harmonijną całość” bądź „technikę tworzenia współbrzmień akordowych towarzyszących jakiejś melodii”. Jednakże w kontekście prawa może chodzić o pewne ujednolicenie poszczególnych małych części składowych w jedną większą.

Kolejnym przykładem, który został zapożyczony z języka angielskiego, jest termin outsourcing oznaczający (również za Słownikiem języka polskiego PWN) oznaczający: „wyłączanie ze struktury organizacyjnej przedsiębiorstwa pewnych funkcji i przekazanie ich do realizacji wyspecjalizowanym firmom". Polska definicja słownikowa jest ekwiwalentem opisowym, swego rodzaju definicją, która jest za długa, 
by się nią posługiwać, dlatego też bardzo trudnym było odnalezienie odpowiednika, który by krótko i zwięźle opisywał dany referent. W rezultacie zastosowano zapożyczenie. dwie grupy:

Według Malinowskiego (2006, 125-126) zapożyczenia możemy podzielić na

1. pochodne słów łacińskich (wiąże się to $\mathrm{z}$ wpływem prawa rzymskiego na polski system prawny), np. apelacja (appellatio), kasacja (cassatio), egzekucja (executio) oraz

2. słowa przejęte $\mathrm{z}$ języków nowożytnych (tj. $\mathrm{z}$ angielskiego, niemieckiego, francuskiego i włoskiego); powodem zapożyczeń jest brak odnalezienia odpowiedniego ekwiwalentu przez polskiego legislatora, np. implementacja od ang. implementation (zamiast wdrożenie).

Takie zjawisko widać również w terminologii japońskiej. Pojęć, jakie wprowadzono w erze Shōwa, szczególnie z prawa amerykańskiego, nie przekładano, ale zapisywano katakana, naśladując wymowę angielską. Jednakże dla zwyczajnych Japończyków, nieznających języka angielskiego, słowa te były niezrozumiałe i sprawiały wrażenie trudnych i obcych, jak terminy w niestosowanych ideogramach kanji. Ostatnio terminy takie pojawiają się również w dużej liczbie (poza prawem cywilnym). Przykładem może być bardzo ważny termin, zrozumiały przez przeciętnych Japończyków, mianowicie „sekushuaru harasumento, セクシュアルハラスメント” (ang. sexual harrassement, pol. „molestowanie seksualne”). W ostatnich latach problem ten często pojawiał się w Japonii, a równocześnie wprowadzono zapożyczenie terminu amerykańskiego. Ponieważ słowo to pojawiło się równocześnie ze zjawiskiem, szybko zaczęło ono powszechnie funkcjonować, zwykle w skróconej formie „sekuhara,セクハラ”. Istnieje również termin o podobnym znaczeniu zapisywany znakami kanji, a mianowicie ,seiteki iyagarase, 性的嫌がらせ”, jednakże nie jest on stosowany i wielu użytkowników języka nie wie, że znaczy on to samo, co znajomy termin sekuhara. Możliwe, że wynika to z niepewności, jaką odczuwają Japończycy, stosując zwroty z ideogramem ,sei, 性”, „płeć”, ,seksualność”. Termin sekuhara jest zrozumiały, a ponadto nie budzi skojarzeń z seksualnością, gdyż zapisywany jest katakana, bez ideogramu.

Również termin „domesutikku vaiorensu, ドメスティックヴァイオレンス” (ang. domestic violence, pol. „przemoc domowa”) używany jest jako termin prawny. Od kilku lat jest to $\mathrm{w}$ Japonii poważny problem społeczny i również ten termin zakorzenił się w języku, niejako mu towarzysząc. Zazwyczaj i w tym przypadku używa się skrótu: „,diivii, DV, ディーヴィー”.

Podobnie jak w przypadku molestowania seksualnego istnieje rodzimy termin „,kateinai bōryoku, 家庭内暴力”, nie jest on jednak stosowany. Być może przyczyną jest słowo bōryoku, sprawiające bardzo „gwałtowne” wrażenie. Takie terminy zapisywane w katakanie pozwalają Japończykom, niechcącym mówić wprost o współczesnych problemach społecznych, na swobodne wypowiadanie się w pośredni sposób. Oto kilka innych przykładów. 
i)

Option (angielski), opushon オプション

Option (angielski), opushon オプション: przy zakupie wartościowego majątku, np. nieruchomości, gdy cała suma nie może zostać od razu zapłacona, płaci się pewną sumę, zabezpieczając $\mathrm{w}$ ten sposób prawo do zakupu w ustalonym terminie. Terminu opushon, オプション używa się nie tylko jako terminu prawnego, ale również w codziennych sytuacjach. Na przykład jeżeli wykupujemy wycieczkę, samolot i hotel, to możliwość uczestnictwa na miejscu w rejsie pełnomorskim lub kilkudniowej wycieczce nazywa się właśnie opushon. W powszechnym użyciu ma to właśnie znaczenie „,zegoś dodatkowego”, trzeba więc uważać, kiedy termin ten stosowany jest w zupełnie innym znaczeniu prawnym.

ii) Franchise chain (angielski), フランチャイズ契約 furanchaizu keiyaku

Franchise chain (angielski), フランチャイズ契約 furanchaizu keiyaku: w ostatnich latach liczba firm, głównie sklepów i restauracji, funkcjonujących na zasadzie franczyzy, znacznie wzrosła, stąd znaczenie tego terminu przebija się do świadomości przeciętnych użytkowników języka japońskiego.

\section{Wnioski}

Przedstawione badania mają charakter poglądowy i miały za zadanie zwrócić uwagę na cechy polskiego i japońskiego języka prawa. Jest to obszerny temat, który ze względu na ograniczenia związane z długością artykułu uniemożliwia dogłębne przedstawienie.

Celem pracy było omówienie wybranych cech japońskiego i polskiego języka prawa i określenie pewnych charakterystyk dla danego języka.

Polska terminologia prawna cechuje się polisemicznością i homonimicznością. Występuje w niej wiele wyrazów archaicznych i latynizmów. Coraz więcej mamy zapożyczeń z terminologii unijnej, ale też i z poszczególnych języków, takich jak: angielski, niemiecki, francuski czy włoski. Jednakże cechą, która dominuje, jest fachowość i specjalistyczność tego języka oraz obecność terminów, które w języku potocznym przyjmują inne znaczenia w kontekście prawnym.

Cechami charakterystycznymi japońskiej terminologii prawnej są m.in. terminy, których znaczenie różni się w języku ogólnym i prawnym, homofony o mniej lub bardziej odmiennym znaczeniu, jak również używanie słów dalekich od ich znaczenia $\mathrm{w}$ codziennym języku japońskim. Pojęcia zaś, jakie te terminy oddają, nie są rdzennie japońskiego pochodzenia, ale zostały przejęte z Zachodu. Czynniki te stanowią znaczną przeszkodę $\mathrm{w}$ procesie rozumienia nie tylko dla tłumaczy przysięgłych, ale zwykłych osób. Obecnie w Japonii podejmowane są starania, by upraszczać terminy prawnicze lub unikać skomplikowanych wyrażeń, co ma ułatwić przeciętnemu Japończykowi zrozumienie zagadnień związanych z prawem. Sytuacja taka jest kolejnym dowodem na to, że słowa wypowiadane czy odczytywane powinny być zrozumiałe i precyzyjnie używane. 
Podsumowując, w obu językach polskim i japońskim, występuje duża zbieżność cech. Co więcej, ilość cech i przykładów, jaka została tutaj przedstawiona może stanowić podłoże do dalszych badań w tym zakresie. 


\section{Bibliografia}

Aizawa, Sachio. 相沢幸夫.1987. Hōritsu yōgo taiyaku shū 法律用語対訳集. Tokio: Shōji hōmu kenkyūkai 商事法務研究会.

Alcaraz Varó, Enrique i Brian Hughes. 2002. Legal Translation Explained. UK \& Northampton, MA: St. Jerome Publishing Manchester.

Bednarczyk, Anna. 2008. W poszukiwaniu dominanty translatorskiej, Warszawa: Wydawnictwo Naukowe PWN.

Bukowski, Piotr i Magda Heydel (red.). 2009. Wspótczesne teorie przekładu, Kraków: Wydawnictwo Znak.

Delisle, Jean, et. al. 2004. Terminologia ttumaczenia, Poznań: Wydawnictwo Naukowe UAM (tłum. Teresa Tomaszkiewicz).

Dolata-Zaród, Anna, 2000. O przektadzie tekstu specjalistycznego. O nauczaniu przektadu, Warszawa: TEPIS Publishing House.

Furuta, Hirokiyo. 古田裕清. 2005. Honyakugo tositeno nihon no hōritu yōgo 翻訳語としての日本の法律用語, Tokio: Chūō shuppanbu 中央出版部.

Hashiuchi, Takeshi 橋内武, i Shūgo. Hotta 堀田秀吾. (red.). Hō to gengo法と言語. Tokio: Kuroshio shuppan くろしお出版.

Jadacka, Hanna. 2006. Stownik poprawnej polszczyzny, Warszawa: Wydawnictwo Naukowe PWN.

Jopek-Bosiacka, Anna. 2006. Ttumaczenie sadownicze i prawne, PWN.

Kubacki, Artur Dariusz. 2012. Ttumaczenie poświadczone. Status, kształcenie, warsztat i odpowiedzialność ttumacza przysięgtego, Warszawa: Wolters Kluwer.

Kubacki, Artur Dariusz. 2013. Teksty paralelne jako narzędzie pomocnicze przy sporządzaniu thumaczeń specjalistycznych. W: Comparative Legilinguistics. International Journal for Legal Communication. red. J. Bańczerowski, A. Matulewska. Poznań: Zakład Graficzny UAM. t. 13/2013, ss. 145-157.

Mattila, Heikki. 2006. Comparative Legal Linguistics. Ashgate.

Matulewska, Aleksandra. 2007. Lingua Legis in Translation. Peter Lang Publishing House.

Matulewska, Aleksandra. 2008. „Jakość przekładu prawniczego a cechy języka prawa” w: Język, Komunikacja, Informacja, Tom III, Sorus SC Wydawnictwo i Drukarnia Cyfrowa.

Matulewska, Aleksandra. 2008. Przyczynek do charakterystyki zmian w polskim języku prawnym od roku 1918 do czasów wspótczesnych. W: Język w urzędach i w sądach II, s. 149-161.

Mellinkoff, David. 1963. The Language of the Law, Boston, Toronto: Little, Brown and Company.

Oksaar, Els. 1989. Alltagssprache. Fachsprachen. Rechtssprache, Zeitshrift für Gesetzgebung.

Pieńkos, Jerzy. 1999. Podstawy juryslingwistyki. Język w prawie - prawo w języku. Warszawa: Muza SA. Oficyna Prawnicza.

Polański, Kazimierz. 1999. Encyklopedia jezykoznawstwa ogólnego, Wrocław: Zakład Narodowy im. Ossolińskich.

Sourioux, Jean-Louis i Pierre Lerat. 1975. Le langage du droit, Paris: Presses Universitaires de France. 
Wróblewski, Bronisław. 1948. Język prawny i prawniczy, Kraków: Polska Akademia Umiejętności.

Wróblewski, Jan. 1987. Zagadnienia polskiej terminologii prawnej i prawniczej. Studia Prawno-Ekonomiczne, t. 39, ss. 14-34.

Zieliński, Maciej. 1999. Polszczyzna 2000, Języki prawne i prawnicze w Polszczyzna 2000. Orędzie o stanie języka na przełomie tysiącleci, red. W. Pisarek, Ośrodek Badań Prasoznawczych, Kraków: Uniwersytet Jagielloński.

Zieliński, Maciej. 2002, 2006. Wykładnia prawa. Zasady, reguły, wskazówki, Warszawa: LexisNexis.

\section{Pozostałe źródła:}

Ustawa z dnia 4 lutego 1994 r. o prawie autorskim i prawach pokrewnych, Dz.U. 1994 Nr 24 poz. 83

知的財産基本法 Japanese Intellectual Property Basic Act,

平成十四年十二月四日法律第百二十二号 Act No. 122 of December 4, 2002, Copyright Act, 1956, 4\&5 Eliz. 2 CH. 74 